\title{
TEENAGE PREGNANCY
}

\section{A CONTEMPORARY PROBLEM OF ADOLESCENCE}

\section{LYNETTE ACRES}

\section{OPSOMMING}

Weens verskeie faktore in die hedendaagse samelewing word tienerswangerskappe 'n gemeenskapsgesondheidsprobleem.

Swangerskap by die tiener het indirekte ekonomiese gevolge weens die lae vlak van skoolopvoeding en die hoër pariëteit wat gewoonlik daarmee gepaard gaan. Verder hou swangerskap by tieners 'n hoër risiko vir die moeder en kind in as by ouer vroue.

Besondere probleme wat deesdae dikwels met tienerswangerskappe saamhang is seksueel-oordraagbare siektes en dwelmverslawing. Die alternatiewe van aborsie en die gee van die kind vir aanneming bring ook albei eiesoortige probleme mee.

Gesondheidspersoneel het 'n rol in die voorkoming van tienerswangerskappe deur gesondheidsvoorligting en die verskaffing van kontrasepsie, asook in die voorsiening van ondersteunende dienste voor en na swangerskap.

\section{A MAJOR COMMUNITY HEALTH PROBLEM}

Teenage pregnancy, particularly pregnancy in school-aged girls below the age of 17 years, is a major community health problem. The incidence of such pregnancies is increasing to what some believe are epidemic proportions.

Girls who become pregnant while still at school, and who continue with their pregnancies, may remain disadvantaged for the rest of their lives. Childbirth in the teenager invariably puts an end to her education and causes a disruption in her relationships with family and friends. Infants born to teenagers have an increased risk of both morbidity and mortality as most are low birth weight infants.

Teenage mothers have considerable difficulty in providing adequate care for their infants - there are defects in mothering which range from inappropriate basic care to neglect and child abuse. This is perhaps understandable in the light of the immaturity of the mother herself. Infant and child care is a demanding task for anyone and is likely to be overwhelming for the teenage mother.

A sociologist stated The girl who has a child at the age of 16 years suddenly has $90 \%$ of her life's script

\section{Acres \\ Senior Tutor, Baragwanath \\ College of Nursing}

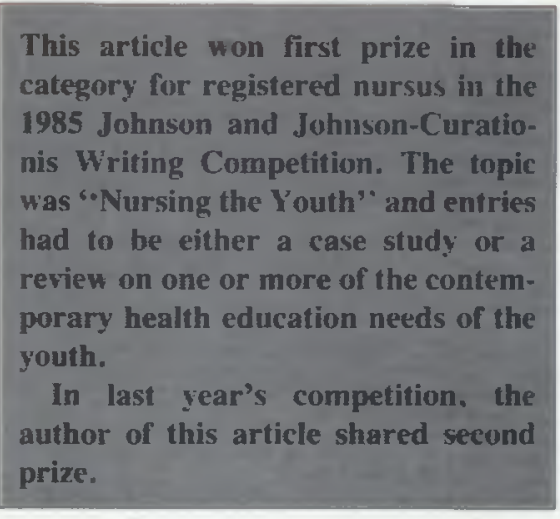

written for her. She will probably drop out of school even if someone else in her family helps her to take care of the baby, she will not be able to find a steady job that pays enough to provide for herself and her child. She may be impelled to marry someone she might not have otherwise chosen. Her life choices are few and most of them are bad. Had she been able to delay the first child, her prospects might have been different. (Campbell, A. 1968 30: 236-237).

\section{CHARACTERISTICS OF ADOLESCENCE}

It would be appropriate to look at some of the psychological and behavioural qualities which are characteristic of adolescence. A thorough appreciation of the needs and concerns of these young people must of necessity determine our approach to the problem of teenage pregnancy.

Adolescence is a time of turbulence, of rapid and tumultuous physical and psychological change.
In this transitional period between childhood and the formation of a stable adult identity, the young person experiments with a variety of behaviours, oscillating between different moral codes and standards testing their own limits and those imposed upon them by society. Sometimes their behaviour takes dramatic and self-destructive forms.

They challenge the standards, views and behaviour of parents and the older generation. Devaluation of the parents and older generation serves to establish the adolescents' individual identity and supports his/her rudimentary independence. The adolescent typically looks to the peer group for support or a set of rules to guide behaviour - the peers become arbiters of appropriate behaviour. Certain behaviours and experiences which would be considered abnormal at any other time of life, are expected and normal during adolescence.

Dramatic mood swings and intense preoccupation with self and one's fantasies are characteristic. The adolescent is a mass of seeming contradictions. They want to make their own decisions, yet fear growing up and losing the emotional and material support provided by the older generation (Brown, W.A. 1980: 49).

Adolescents are strongly orientated to the present, which makes planning for the future difficult. 
Teenagers everywhere need reproductive health care. The kind of care will depend upon where they live and how old they are. For young adolescents the only course of action which is unlikely to affect their health is chastity, and in many countries this is the social ideal for unmarried adolescents. Yet in many societies adolescents are under pressure to be sexually active, the young bride in India/Africa is urged to prove her fertility, whilst the teenager in the West is bombarded with messages from the media saying that those who do not have sexual relationships are missing out.

Premarital sexual activity is common in the developed countries and is increasing in parts of the developing world:

- in the Caribbean Islands, about 58 per cent of first babies are born to mothers aged under 19 years

- in Indonesia, 41 per cent of women have their first baby before they are 17 years old

- in the United States more than a million teenage girls become pregnant every year and about 30000 of them are younger than 15 years (McKay, J. 1985: 8-9)

- in South Africa the number of teenage pregnancies increases yearly (recent statistical figures were unavailable for this article).

\section{OUTCOME FOR TEENAGE MOTHERS AND THEIR OFFSPRING}

\section{Economic impact}

The economic impact of teenage pregnancy is not direct. Rather, it seems to trigger a chain of events that continue to undermine economic well-being. One critical factor is the reduction in educational attainment followed by higher subsequent child bearing, lower income and marital instability.

Although the number of years of schooling completed does not appear to affect the amount of work experience a woman accumulates, it does affect the occupational status and earning of workers. Women with less schooling obtain jobs of lower socio-economic status, make lower hourly wages, and earn less annually. Therefore, an early pregnancy can be said to indirectly reduce occupational status and earnings through its effects on schooling (See figure 1).

In figure 1 there are two arrows between education and the age of the first pregnancy. This represents the belief that not only does the age at which a woman bears her first child affect the number of years of schooling she will complete, but that her schooling affects the age at which she bears her first child. Thus there are two distinct patterns:

- a first birth to a teenager precipitates dropping out of school

- dropping out of school for reasons other than pregnancy is nevertheless followed by pregnancy.

In general, teenage mothers are considered to follow the first pattern, whilst older mothers tend to terminate their schooling prior to becoming pregnant (Scott. K.G. et al. 1981: 48).

\section{Risks of pregnancy}

When considering the risks of pregnancy it is important to distinguish between younger and older adolescents. For women aged 18 or 19 years their youth barely adds to the hazards of pregnancy. Where age seems to make the most difference is for girls who become pregnant when they are 15 years or younger. The risk for these girls to die in pregnancy is $60 \%$ higher than for pregnant women in general. The two main obstetric risks of early pregnancy are toxaemia (Pregnancy Induced Hypertension), which can endanger the life of the mother and the foetus, and cephalopelvic disproportion. The young teenager is physically immature with an inadequate pelvis leading to a prolonged labour and often preventing a normal vaginal delivery.

Figure 1 Effects of age at first pregnancy

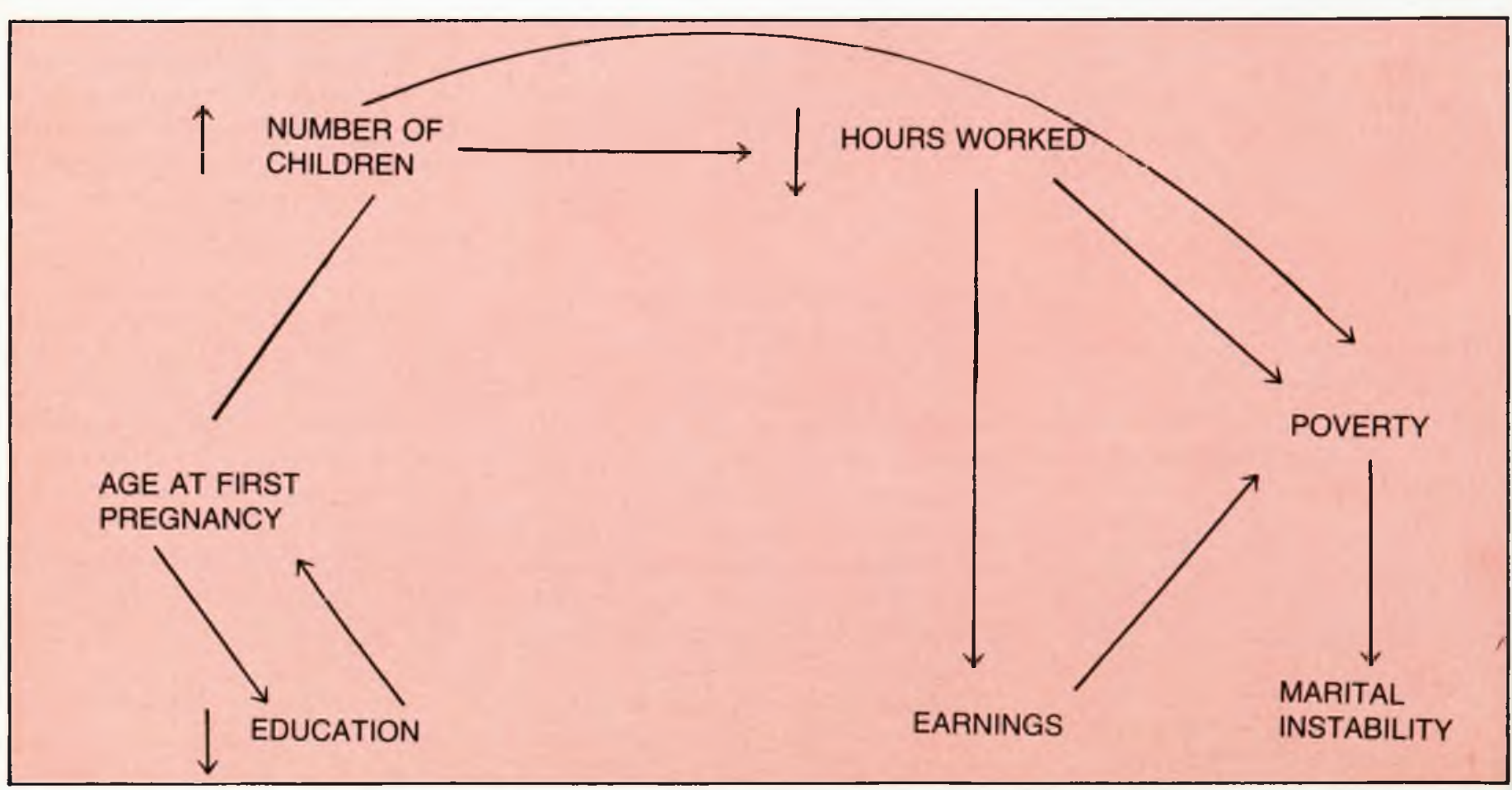


Adolescent mothers have an increased fertility and foetal wastage, that is, they have on average more live born children yet a greater proportion of foetal loss than the older woman.

\section{Risk to the baby}

The risk to the baby is that of a low birth weight, due either to prematurity or the delivery at term of undernourished babies. These babies are more likely to die at birth or in infancy and physical and mental development may be impaired.

\section{Sexually transmitted disease}

Sexually transmitted disease is another health risk. It has been suggested that there is an increased incidence of venereal disease in the young adolescent. Two factors are related to this. First, increased adolescent sexual activity, and second, decreased use of condoms which provide a mechanical barrier to the transmission of venereal disease (Webb, G.A. et al. 1972: 511).

If the pregnant teenager presents late for prenatal care or is admitted to the health services only when in labour, then prevention and cure of these diseases becomes more difficult and thus transmission of congenital venereal disease to the infant more likely.

Good obstetrical services will reduce most risks to both mother and baby. However, in cases where the baby is unwanted and possibly illegitimate, or the mother very young or poor, the mother is less likely to take advantage early enough in the pregnancy of whatever care is available to her.

\section{Drug abuse}

The teenage population has been suggested to be at higher risk for drug abuse. Drug abusers should be identified as soon as possible, as the intake of pharmacological agents on a chronic basis increases the prematurity rate, congenital abnormalities and the rate of complications during pregnancy.

If drug dependency is found in an adolescent, the situation requires very careful management. Therapy for the drug dependent pregnant teenager depends on whether she requests withdrawal during pregnancy or remains an addictive obstetric patient. With adequate prenatal care there is a chance of reducing the risks associated with pregnancy in this special group of patients. Unfortunately, the general outcome of these pregnancies is not encouraging and, in addition. the compliance rate is low (Hollingsworth, D.R. et al. 1978: 12).

\section{Abortion}

For some young women there is the option of abortion, although this is a controversial, and in many countries illegal, procedure. Estimates suggest that between 30 and 55 million induced abortions take place annually throughout the world and a substantial proportion of these involve teenagers (McKay, J. 1984: 8-9).

The hazards of illegal abortion, usually done by unskilled practitioners, are well known. However, even in countries where abortion is legal it is the pregnant adolescent who is least likely to seek an abortion early in pregnancy when abortion presents the smallest risk to her health. This may be because adolescents do not realise that they are pregnant, and if they do know, they find themselves vainly hoping the pregnancy will go away or they are inhibited from taking early action for some other reason.

\section{Adoption}

The great majority of women who place their children for adoption are teenagers. However, the availability of abortion had led to a drastic reduction in the number of women who bear children and place them for adoption. Clinical impressions of women who have placed their children for adoption suggest that these women do not suffer gross psychiatric disability, but they do experience prolonged unresolved guilt, sadness, and yearning for the abandoned child (Brown, W.A. 1980: 60).

The woman who chooses the alternative of adoption will be beset with conflict and misgivings. It is best that the presence of such conflicts be acknowledged by both the health professional and the pregnant woman. Whether or not the woman who is placing her child for adoption should have contact with the infant during the days immediately following delivery is a point of considerable controversy. In the absence of definitive information about the consequences of contact with the infant, we can do no better than to leave the decision up to the mother. Many people have an intuitive sense about what is best for them and how best to cope.

\section{EARLY INTERVENTION}

The prevention of teenage pregnancy involves ethical, legal and educational as well as health care issues. Health professionals by virtue of their knowledge, their authority and their access to developing young people and their families are being called upon to remedy this increasingly complex and worrisome problem. They are called upon to counsel and provide care for sexually active adolescents and to serve as consultants to schools and other community organisations involved in family planning.

Whether they are sexually active or not, attention to the sexual questions and concerns of all adolescents is warranted. Explicit information about sexuality, reproduction, contraception and access to birth control devices is required.

Discussion about sexuality, information about birth control and provision of birth control devices are unlikely to stimulate the young person to engage in sexual intercourse. These approaches may, however, protect the sexually active girl from unwanted pregnancy. The adolescent should be introduced to Family Planning before, and not after, pregnancy.

It is worthwhile emphasising the critical importance of not forgetting the adolescent and her baby after delivery. Intensive and frequent support relating to infant care and the mother's emotional, educational and vocational needs is essential if increased child bearing and marital instability are to be prevented. Those most in need of such services are the single mothers who do not return to their families.

Continued on p. 40 